\title{
Do democracies provide better education? Revisiting the democracy-human capital link
}

December 9, 2016

\begin{abstract}
We investigate whether democracy enhances the skills and knowledge of citizens through improving education quality. This, in turn, could have ramifications for other development outcomes such as economic growth. We offer the first systematic crossnational study on democracy and education quality. Democracy is widely regarded as superior to autocracy in terms of providing access to education, and several studies find that democracy enhances educational enrollment and years of schooling. Yet, we do not know whether democracies provide better education. We argue that democracies should not too readily be expected to outperform autocracies on education quality. First, it is inherently difficult to implement quality-enhancing education reforms, even for well-intentioned (democratic and autocratic) governments with ample resources. Second, education quality is less visible to voters than, e.g., expanding education enrollment, making quality-enhancing policies a less attractive option for office-seeking democratic politicians. We employ a recent dataset comparing international student tests for 128 countries, from 1965 onwards. While democracies typically provide "more" education than autocracies, we find no systematic evidence that democracies offer better education. The result is very robust and holds in both cross-section and panel specifications. The null-relationship is not explained simply by democracies providing education access to more (and different types of) children than autocracies, and it appears both in rich and poor and in low- and high-capacity states. We also present relevant nuances: For instance, autocracies display more variation in education
\end{abstract}


quality outcomes than democracies, and we find some evidence that democracy may be associated, more specifically, with better reading skills. In sum, this study provides new insights to the democracy and education literature, where extant studies often report strong links between democracy and various education outcomes not directly related to education quality, and informs literatures linking democracy to development outcomes such as growth via effects on human capital.

Keywords: Democracy; Education; Education quality; Student achievements; Human capital 


\section{Highlights}

- We find that democracy enhances measures of education quantity, such as average years of schooling, in line with extant studies.

- But, democracy does not clearly affect the quality of education that students receive, and this null-result is very robust.

- This can be explained by a) the difficulty of improving quality with political tools and b) weak electoral incentives to promote quality.

- The null-result on democracy and education quality does not seem to come from democracies sending more kids to school.

- Yet, democracies display less cross-country variation in education quality outcomes than autocracies. 


\section{Introduction}

We investigate the relationship between political institutions and education quality, which is closely linked to the knowledge and skills (i.e., "human capital") obtained by citizens during their years in school. More specifically, we ask: Do democracies provide citizens with an education that raises their knowledge and skill levels relative to the education provided in autocracies? To foreshadow the conclusion, our empirical analysis suggests that democracy does not systematically relate to citizens' knowledge and skills.

While education quality and the resulting human capital can be considered important development outcomes in their own right (e.g., Sen, 1999), any effect of democracy would arguably have broader developmental ramifications since human capital is anticipated to affect a range of social and economic phenomena. Human capital is, for example, typically considered among the key ingredients for generating economic growth (e.g., Mankiw, Romer and Weil, 1992; Lucas, 1988; Benos and Zotou, 2014). Early empirical analysis of human capital and growth often employed measures such as years of schooling or school enrollment ratios to proxy for human capital (e.g., Mankiw, Romer and Weil, 1992). Yet, economic growth theory is not merely concerned with "the quantity of schooling" offered to students, but rather the skills and capabilities that (prospective) workers acquire, in school or otherwise. Years of schooling or education spending are, at best, only distant proxies of human capital. Acknowledging this, the growth literature has recently turned its focus towards more valid proxies of human capital. More specifically, it has started taking education content into account, revealing - as theoretically expected - that education quality is a much stronger determinant of growth than indicators of "education quantity". For instance, Hanushek and Woessmann (2008a) find that cognitive skills are positively related to growth, and that any positive effect of education quantity disappears when controlling for skills (see also Hanushek and Kimko, 2000; Hanushek and Woessmann, 2008b). ${ }^{1}$ Further, the human capital stock in developing countries has likely been exaggerated when using indicators such as enrollment rates and average years of education (see, e.g. Glewwe, Maiga and Zheng, 2014). ${ }^{2}$ Also differences in long-run growth performances across OECD countries can be explained by variations in education quality, as opposed to education quantity (Hanushek 
and Woessmann, 2011). Hence, understanding the determinants of education quality is important for understanding economic development.

Democratic political institutions have long figured among the proposed determinants of human capital. A vast literature, drawing on contemporary and historical data from different regions of the world, suggests that democracies are more likely than autocracies to provide more education to their citizens (Lake and Baum, 2001; Bueno de Mesquita et al., 2003; Lindert, 2005; Brown, 1999; Brown and Hunter, 2004; Stasavage, 2005; Engerman and Sokoloff, 2005; Engerman, Mariscal and Sokoloff, 2009; Ansell, 2010; Gallego, 2010; Huber and Stephens, 2012; Acemoglu et al., 2015; Harding and Stasavage, 2014). Countries experiencing successful democratic transitions can thus, over the coming years, expect lower schooling fees, a larger share of their children enrolled into primary and secondary school, and that their youth will, on average, spend more years in school (but, see Murtin and Wacziarg, 2014). Indeed, different statistical studies have suggested that education is among the key mediators through which democracy enhances economic growth (Baum and Lake, 2003; Tavares and Wacziarg, 2001; Doucouliagos and Ulubasoglu, 2008). However, also these studies have drawn on measures of "education quantity", such as secondary school enrollment rates, to proxy for human capital. In order to more directly evaluate the effect of democracy on human capital, and thereby also the potential indirect effect of democracy on growth via human capital, we need to study how regime type affects education quality.

One might intuitively expect the clear answer to the question of whether democracy promotes education quality to be "yes". Why would voters not pressure politicians to give their kids a high-quality education, and not only increase the number of years they stay in school? In autocracies, truly competitive elections are lacking, leaving citizens with one less tool available for pushing for an education system that properly teaches their children skills such as reading and basic mathematics. Instead, autocratic regimes might expend effort and resources to provide high-quality education only for the children of their (often fairly narrow) supporting groups, or use the national education system to indoctrinate government ideology. A plausible hypothesis is thus that democracy enhances not only education quantity, but also education quality. Yet, we retain that this is an open empirical question: First, previous empirical studies suggest that education quality is intrinsically hard 
to increase by legislation or by simply increasing the education budget (see, e.g., Hanushek and Woessmann, 2008a). If political choices have little bearing on education quality, the link between regime type and such quality should be weak. Second, democratic politicians may not have strong incentives to even try to increase education quality after all. Following Harding and Stasavage (2014), we highlight that the quality of education (and the policies that may improve it) is often difficult to verify and monitor by voters. Hence, in a world of budget constraints, democratic politicians may be wise to rather channel resources to measures increasing (more visible) features associated with "education quantity".

With one notable recent exception (Harding and Stasavage, 2014), there is a lack of systematic empirical studies on regime types and education quality. The main reason is presumably that cross-country data on education quality have previously been scarce. We employ the recent dataset by Angrist, Patrinos and Schlotter (2013) containing comparable measures on international students achievements tests in mathematics, reading, and science from 128 countries. We thus provide the first systematic analysis drawing on cross-country data to assess the relationship between democracy and education quality.

To quickly summarize our results, we first replicate the finding that democracy is positively related to standard measures of education quantity, namely average years of schooling and primary and secondary enrollment ratios. But, the core finding - which is a novel, important, and perhaps (to many) surprising null finding - is that democracy does not systematically relate to education quality. While we acknowledge the possibility that this null-result could partly stem from measurement errors and other aspects with the data, and should thus not be viewed as entirely conclusive, the result does hold across different cross-section and panel specifications, different samples, and for different measures. One might hypothesize that the null-relationship between democracy and nation-wide measures of education quality is simply due to expansion of enrollment rates under democracy; more students entering school puts pressure on teaching facilities and new groups with worse initial prospects for learning (such as kids living in poor rural areas) are channeled into the schooling system. However, we find no clear support for this alternative explanation. Democracy is not associated with education quality, on average, even when accounting for the expanded access to education. Neither do we, when looking beyond the average per- 
formance of countries, find that democracies have smaller differences between good- and bad-performing students, though this result is based on far more limited data material. That being said, we do find that autocracies clearly display more cross-national variability in terms of aggregate education quality outcomes. While democracy does not relate to better education quality on average, democratic countries are less prone to observing extremely poor (and extremely good) outcomes.

In sum, democracy may increase the number of kids in school, but it does not, in general, clearly improve the measurable capacities, skills and knowledge of its young citizens. While democracy may increase economic growth through other channels, our findings thereby also cast doubt on the anticipated indirect effect of democracy on growth via improving human capital, since the first link in this chain is not robust.

The paper proceeds as follows: In Section 2, we review relevant literature on democracy and education. Thereafter, in Section 3, we elaborate on the argument for why democracy might not lead to higher-quality education outcomes. In Section 4, we present the data, focusing on our preferred measure of education quality. We present the empirical analysis in Section 5, before concluding and pointing to avenues for future research in Section 6 .

\section{Democracy, education, and education quality}

The literature suggests very plausible reasons for why democracy improves outcomes associated with "education quantity". In brief, democratic politicians accountable to a wide constituency - many of whom have kids in schooling age - are incentivized to respond to calls for lower school fees, or expand education access to large population groups in order to be re-elected. Extant empirical studies use education measures that reflect these arguments such as enrollment rates, share of the population having completed primary, secondary and tertiary education, or the abolition of school fees. We will not survey this vast literature in its entirety, but mention some prominent arguments and results:

Lake and Baum (2001) describe how political competition within democracies generates political dynamics that increase the provision of public services at the expense of rents extracted by leaders. In contrast, autocratic politicians can extract substantial rents by 
limiting such services without facing grave consequences. A slightly different argument for why democracy widens access to and increases funding of education is provided by Bueno de Mesquita et al. (2003). They highlight that broad-based education systems can be characterized as public goods, and that investing in such systems is a cost-effective way to maintain political support for leaders with large "winning coalitions" (as in democracies), and relatively expensive for leaders with small coalitions (as in many autocracies). Acemoglu and Robinson (2006) theorize that the relatively poor majority will push for universal schooling under democracy, where the poor hold more political power, whereas autocratic elites will shun such expensive schooling systems, which also benefit the non-elites (see also Meltzer and Richards, 1981; Saint-Paul and Verdier, 1993; Boix, 2003; Ansell, 2008; North, Wallis and Weingast, 2009). Finally, Stasavage (2005), focusing on the African context, develops a model explaining why democratically elected leaders will invest more in primary education. Populous rural groups in African countries have clear preferences for spending limited public resources on primary education rather than policies benefiting urban elites, such as expensive university systems, and these rural groups face far lower costs of organizing collective action under democracy than autocracy (see also Bates, 1981). ${ }^{3}$

Concerning empirical analysis, Lake and Baum (2001) report a strong positive crosscountry correlation between democracy and various proxies of human capital, including measures of persistence of students to the fourth grade, different school enrollment ratios, pupil-teacher ratio, and literacy rates (the latter two can, admittedly, be considered as crude proxies of education quality). But also several other studies - including case studies, small-n comparative studies and statistical studies employing time series variation - suggest that democracy expands access to and improves funding of both primary and secondary schooling (Lindert, 2005; Stasavage, 2005; Engerman, Mariscal and Sokoloff, 2009; Huber and Stephens, 2012). For instance, the historical expansion of access to lower-level education in the US, UK and Scandinavian countries seemingly followed from the expansion of political rights, and suffrage extensions in particular, during the 19th and early 20th century (see Lindert, 2005). Studying post-colonial Africa, Stasavage (2005) shows that democracy relates to spending on primary education in particular, and Harding and Stasavage (2014) detail how elections lead to subsequent abolition of school fees. They also report evidence 
from surveys of Kenyan voters suggesting that they condition their voting behavior on school fees being abolished, providing more direct evidence for the type of theoretical argument reviewed above.

One concern is that the above findings reflect a causal effect running from education to democracy - such an effect is among the central propositions of "modernization theory" (e.g., Lipset, 1959), and the empirical study by Murtin and Wacziarg (2014) suggests that the correlation mainly reflects a "reverse effect". Nonetheless, other stringent studies (e.g., Acemoglu et al., 2005) do not find that education systematically enhances democracy, casting doubt on the reverse relationship, and yet other identify a causal effect of democracy on measures of education quantity even when accounting for the potential endogeneity of democracy (e.g., Gallego, 2010; Acemoglu et al., 2015). Hence, while contested, a substantial effect of democracy on, for instance, lower-level school enrollment or years of schooling seems more plausible than not.

\section{Why democracy may not enhance education quality}

Thus, democracy likely improves access to education. However, we can not automatically expect democracies to provide better schooling than autocracies. Following Harding (2015), we contend that vote-seeking democratic politicians are incentivized to provide better public policies only when it comes to certain public services. More specifically, responsibility for the quality of the particular public service should be easy to trace back to the elected officials and the service provision should be transparent, in the sense that voters can verify whether improvements have been made. Further, the public service in question must be linked to an available policy that is within the reach and capacity of elected official to effectuate. We discuss below how education quality does not have these characteristics, making it less feasible for politicians to pursue as a way of boosting popularity.

There are two parts to our argument. First, education quality is hard to verify and is often not attributed to the central government. This reduces the incentives of vote-seeking politicians to pursue legislation or other measures anticipated to improve education quality. Second, democratically elected politicians (as well as autocratic) may simply be incapable 
of increasing education quality even if they desire to do so. There is fairly strong evidence that the quality of education systems is (highly) path dependent, and does not respond clearly, and especially not immediately, to pieces of legislation - which may also be hard to implement effectively in the education area - or to increased education spending. We elaborate below.

\subsection{Democracy and incentives to improve education quality}

First, there are reasons to expect that improvements in education quality may not be a very effective way of gathering public support, and this reduces the incentives of democratic incumbents (and opposition leaders) to pursue policies that may enhance education quality. Whereas a democratic system creates strong incentives for office-seeking politicians to expand education enrollment, it does not necessarily incentivize them to pursue quality-improving programs.

One reason is that improvements in education quality are not easily verifiable for the average voter (see also Harding and Stasavage, 2014), whereas, e.g., expanding access to schooling (or abolishing school fees) is fairly visible to voters: Experiencing that your child or grandchild finally gets to go to school will likely make a clear impression. In contrast, few citizens have exhaustive knowledge about the quality of an education system. Investments in measures that improve student achievements, such as developing new methods of classroom teaching, are often less transparent (Harding and Stasavage, 2014). Thus, they are difficult to promote and explain at campaign rallies or televised debates. ${ }^{4}$ The opaque relationship between specific policy measures and improvements in education quality means that incumbents are less likely to convince retrospective voters, even those concerned with education outcomes, in the next election.

Another reason why democratic incumbents may not be punished for neglecting education quality is that it is often not clearly attributable to the central government (see Harding, 2015). While policy reforms such as abolishing school fees, implementing mandatory schooling laws, or removing formal barriers to entering schools can be clearly traced back to government policies, poor education quality can often not. Low education quality can be caused by lack of school equipment or poor facilities, and these factors are commonly 
managed at the local level. Meanwhile, poor teaching is often attributed to characteristics of the teacher or the school, rather than the central government.

If education quality does not attract much popular support, democratically elected leaders may even accept a depreciation quality in order to, for instance, raise enrollment rates (Michaelowa, 2001). This is particularly pertinent for governments presiding over limited financial resources. Addressing the Ugandan abolishment of primary school fees in 1996, Stasavage (2005) argues that it was most likely the introduction of democratic politics that prompted President Museveni to promise and implement this reform. Stasavage points out that while the Ugandan education reform secured universal primary education, the massive expansion in education enrollment was followed by a drop in education quality - possibly due to subsequent shortage of basic materials and a dramatic increase in pupil-teacher ratios. Likewise, Colclough and Al-Samarrai (2000) suggest that increased enrollment ratios in Sub-Saharan Africa and South Asia has often been achieved by lowering the "unit costs" of schooling. Studying education policy in current England, Jennings (2015) argues that also other education policies (such as banning private schools) may be supported by many voters on ethical (and sometimes instrumental) grounds, leading to "expressive voting" for such policies even if they induce sub-optimal education quality outcomes. Hence, there may even be negative effects of democracy on education quality due to the types of education policies that are electorally attractive. For a democratic government, expanding education enrollment is a powerful tool for satisfying constituencies, whereas improving education quality is less visible to voters. The latter is thus less likely to be prioritized by elected officials, particularly if budget constraints force a trade-off between quality-enhancing measures and expanding education access.

Survey evidence from Kenya illustrates that education quality does not strongly affect popular support, as intentions to vote for incumbent President Kibaki was not affected by poor and even deteriorating quality (Harding and Stasavage, 2014). Meanwhile, these authors also find that a reform abolishing school fees (and raising enrollment) clearly did increase support for the Kenyan president. Further, studying Ghana, Harding (2015) finds evidence supporting the "attribution argument" discussed above, showing that services that are easily attributable to the government, including roads and number of primary schools, 
increase incumbent vote share. In contrast, factors such as classrooms per school and school facilities - which are provided at the district level - does not affect voting behavior. These results constitute fairly direct evidence supporting of the first (electoral incentive) mechanism in our argument.

While democratic governments are not necessarily incentivized by electoral competition to improve education quality, they may still want to improve it for other reasons such as growing the economy. However, dictators often have similar such incentives. In dictatorships where incumbents rely on patronage and economic co-optation of their "ruling coalitions", having extra financial resources serves as a buffer against political instability (e.g., Geddes, 1999; Bueno de Mesquita and Smith, 2009). Dictators may also invest in human capital, and increase production, in order to strengthen the country's capacity to withstand external security threats (e.g., Thyne, 2006; Knutsen, 2011b). Hence, dictators and democratic leaders may face resembling incentives for promoting education quality.

\subsection{Democracy and obstacles to improving education quality}

Second, politically engineering improvements in education quality is inherently difficult. Even when democratically elected politicians are genuinely motivated to bolster the quality of schooling, the intended outcome is not ensured. Indicatively, different studies find no straightforward relationship between education spending and educational outputs (e.g., Hanushek and Kimko, 2000). One reason may simply be that it is hard to determine what exact policies are effective at enhancing student learning, as is reflected in the field of education research. It is, for example, still unclear which types of (and even whether) homework boosts learning (Cooper, Civey Robinson and A. Patall, 2006), what manipulable factors determine teacher quality (Harris and Sass, 2011), and whether number of students in the classroom affects learning (Hoxby, 2000). Given this lack of established knowledge about ways to improve education quality, there is little reason to expect that democratic leaders have profound insights into effective learning enhancers. Even some of today's rich, advanced democracies such as Norway and the United States, where politicians at the very least pay lip-service to raising education quality, struggle to improve it.

Such uncertainty not only makes it difficult to identify exactly what a quality-enhancing 
education reform looks like in practice, but it also provides fodder for those opposed to resource-demanding education reforms. More generally, even if democratically elected politicians happen to know the "cure" against poor student achievements, they often face wellorganized interest groups that make legislating and effectively implementing education reforms difficult. Organized special-interest groups may, for various reasons, be particularly strong in established democracies (Olson, 1982), and markedly influence policy-making in "their" respective areas. One interest group that has received much attention in the literature is organized teachers' unions. Although teachers' unions should prefer more investments in the education sector, their members will often bear different costs associated with reforms, inducing unions to work against them (Loveless, 2011; Moe, 2011). For example, there is evidence documenting the efficiency of policies that link salaries to teachers' performance, but such reforms are commonly impeded by organized interests. Teachers' unions in the U.S. have in practice blocked any merit pay reforms (Hanushek, 2016). Meanwhile, the strong Mexican teachers' union has worked to promote merit pay, but has exploited it to increase salaries while working to minimize requirements for moving up the payment ladder, thereby preventing the reform from boosting quality (Hecock, 2014). Hence, even if democratically elected governments were blessed with knowledge about the policies that boost education quality and would want to invest in and prioritize them, these policies may be difficult to implement..$^{5}$

In sum, the uncertainty concerning what quality-enhancing reforms actually look like, and the difficulty of implementing education reforms, may help explain why previous studies have shown that a society's overall level of skills and knowledge is strongly path-dependent (see, e.g., Crayen and Baten, 2010; Baten and Juif, 2014). Enhancing education quality is difficult to achieve by the stroke of a pen, even if the pen is held by an education minister, prime minister or president. This suggests that politics more generally, and the political regime type more specifically, may not strongly affect education quality.

Now, presiding over a well-functioning, non-corrupt state with high capacity might help politicians overcome opposing interest groups in passing different reforms, including education reforms. A high-capacity bureaucracy might also enable politicians and bureaucrats to overcome the difficult issue of discerning and evaluating information on which reforms 
actually work. As such, institutional features that enhance the "quality of government" (Rothstein and Teorell, 2008) could be important for achieving the desired policy outcome (Rothstein, 2011). Insofar as democracy enhances "quality of government" (see Charron and Lapuente, 2010), it could therefore indirectly enhance education quality. However, the link between such institutional features and education quality may be weaker than the link with other outcomes, simply given the extent of the informational problems on what constitutes a quality-enhancing education reform. And, as discussed, having the capacity to implement the appropriate education reforms does not suffice; politicians need to be motivated to pass such reforms in the first place, and democratic accountability mechanisms may not work particularly well in this issue area.

\subsection{Some suggestive evidence and observations}

The relationship between democracy and education quality has previously not been systematically evaluated using cross-country data. But, the proposition that democracy does not, in general, enhance quality seems to be supported by some suggestive evidence. For instance, PISA test score studies reveal large variations in student achievements - which, as we argue below, is a strong indicator of education quality - among OECD democracies (see Fuchs and Woessmann, 2008). Further, there seems to be large variation in education quality also across autocratic regimes. In some autocracies the education system focuses on indoctrinating government ideology, and less on basic writing and math skills or knowledge of science. One example is North Korea, where students spend more than one-third of their time on "political education" in the Juche ideology (Martin, 2004, 167). Other autocracies have historically had high-quality education systems. 19th century Prussia had a highquality system that was widely emulated by other countries (see, e.g., Lindert, 2005; Clarke, 2006). The quality of the education in mathematics and the natural sciences in the Soviet Union and other Eastern European Communist regimes was considered high (Boesman, 1993; Balzer, 1993; Chengze, Overland and Spagat, 1999). South Korea and Taiwan are two more recent examples, with students achieving top scores on cross-national skills tests before democratization (Stiglitz, 1997, 884), but also after. We proceed by investigating the relationship between regime type and education quality more systematically. 


\section{Data, measures and validity issues}

\subsection{Measuring education quality}

We assume that education quality is strongly related to the actual skills and knowledge (i.e., human capital) that students gain from schooling. Indeed, our interest in education quality is, in large part, driven by a concern with the knowledge and skills that students actually acquire through their education. The latter is the outcome often hypothesized to, in turn, produce various other beneficial outcomes such as economic growth.

Thus, we draw on measures of students' knowledge and skills to operationalize education quality, and more specifically a measure using international student achievement test scores. Although there are several challenges related to measuring education quality (and also skills and knowledge more directly), we submit that our preferred indicator comes close to capturing the outcome of interest, and far closer than more distal proxy indicators such as education spending or even the ratio of teachers to students. The latter measure education inputs rather than education outputs. While we acknowledge and discuss validity issues and limitations below, we first describe and highlight the beneficial aspects of the data, for example the coverage:

Angrist, Patrinos and Schlotter (2013) provides the first dataset on student achievements tests across a majority of countries globally, covering 128 countries around the world measured in 5-year intervals from 1965-2010. This is a clear extension of the cross-sectional coverage of previous datasets (up to about 50 countries), which directly resulted from the limited coverage of any single international achievement test such as PISA. Building on Hanushek and Woessmann (2012a), Angrist, Patrinos and Schlotter (2013) solves this by linking regional tests to international tests using countries that participated in both as reference points. Further, different international assessment tests are linked by using the United States - which has participated in almost all tests since their inception - as a reference point. Thus, regional assessments such as "South and Eastern African consortium for Monitoring Educational Quality" (SACMEQ) and the "Latin American UNESCO Laboratorio Latinoamericano para la Evaluacion de la Calidad de la Educacion" (LLCE) are converted to the same metric as international assessments such as PISA and Trends in International 
Mathematics and Science Study (TIMSS). All surveys included are conducted among students enrolled in primary or secondary schools, and we further detail the different surveys included and how the Angrist et al. dataset and our baseline measure of education quality is constructed in Appendix Section A.1.

Our main measure of education quality is the composite measure from Angrist et al. that aggregates both primary and secondary level test-score performances for mathematics, reading and science. The measure ranges from 0 to 100 theoretically, and from 13.9 (Mauritania-1995) to 74.3 (Japan-1980) empirically, with a mean of 45.8 and standard deviation of 9.7. The Angrist et al. dataset also contains disaggregated test score measures on the three different subjects for each of the two education levels. We employ these disaggregated measures in extensions of our main analysis.

Figure 1 shows that education quantity, measured as average years of education (for 15-year olds+; the pattern is very similar when using data on 25-year olds+) from the Barro and Lee (2013) dataset, is correlated with our preferred measure of education quality by .60. Hence, countries with higher education quantity are, on average, more likely to have higher quality, but many observations also deviate from this pattern. Japan is the country with the highest observed score on student achievements, but on average years of schooling Japan does not even fall within the top 25 percentile in our sample. Countries such as Jordan and South Africa, on the other hand, perform better on quantity than, say, China in 1990 (only 5.6 years of average schooling), but their education quality is dramatically lower than China's. Indeed, when accounting for income level - which presumably affects both the quality and quantity of education provided - the partial correlation between average years of schooling and mean student achievement test score is only .20 .

Despite capturing central learning outcomes that should be strongly linked to education quality, and despite the thorough measurement modelling and extensive information used to generate the Angrist et al. measure, there are potential validity issues. First, even though different test scores in different subjects and at different levels of education are included, there may still be noise in the measure. Unsystematic measurement error in our dependent variable would not systematically bias regression results, but would increase standard errors. Still, given that the coefficient on democracy flips sign between models, and t-values are very 
Figure 1: Average years of schooling for 15-year olds+ (from Barro and Lee (2010)), and "schooling achievements" (measured by aggregated student achievements measure from Angrist (2013)).

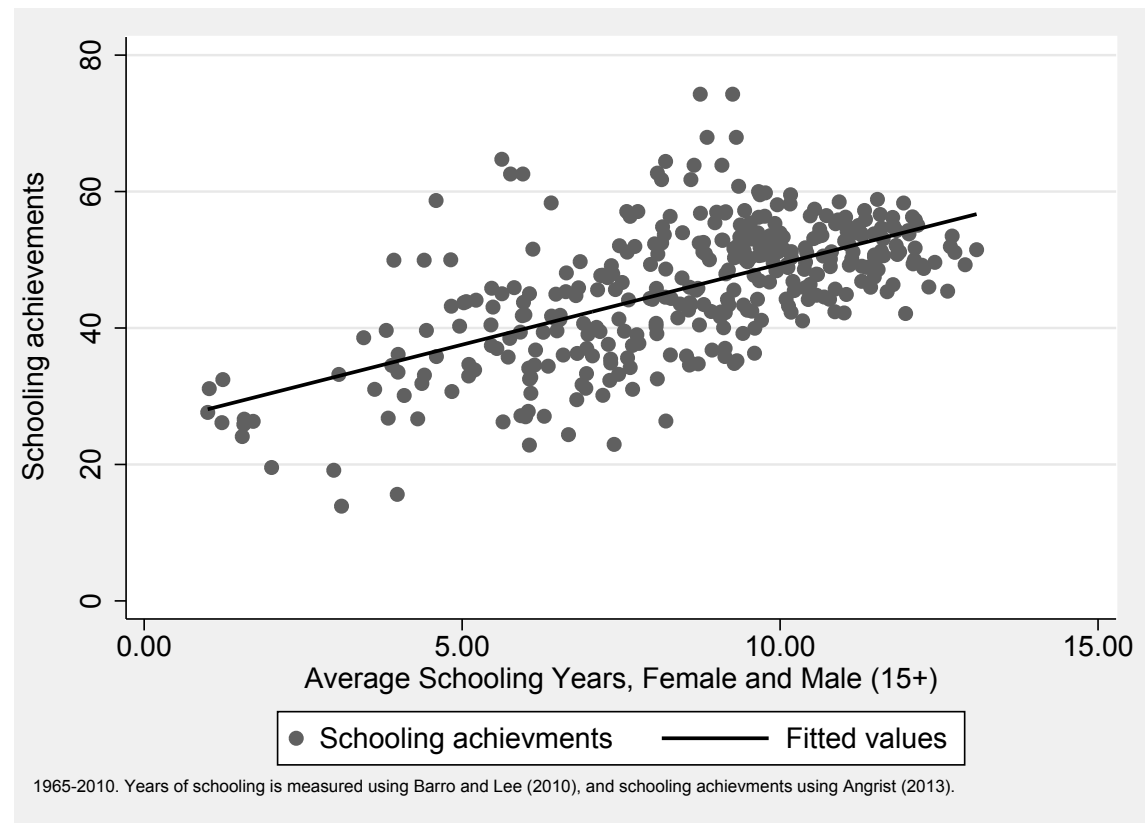

low, it is implausible that this is driving our results; the magnitude of such errors would have to be (unrealistically) high to explain our results.

Second, and potentially more problematic, there could be systematic errors in our education quality measure. One well-known example is that China only conducts PISA tests in Shanghai (plus in Macau and Hong-Kong), and students in this relatively wealthy urban area presumably score better on such tests. China alone does not drive our results - we re-ran our regression omitting China, and results are almost identical. But, if autocracies, in general, only allow areas with expected high-performing students to participate, or otherwise manipulate test scores more blatantly than democracies do, we will underestimate the relationship between democracy and education quality. Hence, we cannot completely exclude the possibility that our results are produced by several authoritarian regimes manipulating their test scores. However, such a measurement-induced bias must be very large in order to explain our very clear null-results. Further, if "manipulation", such as testing only particular schools or areas, is fairly stable within countries - persisting also after democratization - then controlling for country-specific effects should mitigate biases. The country-specific effects should also mitigate biases potentially related to PISA and other tests capturing 
particular topics and skills (within mathematics, reading and science) that are emphasized more in some countries than in others due, e.g., to cultural or historical differences.

Third, our main measure is based on test results for mathematics, reading and science. If one operates with a fairly broad concept of education quality, and democracies tend to put more resources into, and enhance learning outcomes in, subjects such as social sciences and civics education, we could potentially underreport differences in education quality. This is a plausible hypothesis, which we unfortunately cannot test given the lack of measures with comprehensive coverage. If data become available, future research could test for regime differences in education outcomes outside the core areas of mathematics, reading and science. With these caveats in mind, we proceed to our empirical analysis.

\subsection{Data and measures for democracy and control variables}

We employ the Polity Index from the Polity IV Project (Marshall, Gurr and Jaggers, 2013) as our main measure of democracy, and report results for other democracy measures in the appendix. ${ }^{6}$ Alongside the Freedom House Index, Polity is the most widely used democracy measure in the literature addressing relationships between democracy and education variables. Polity ranges from -10 to +10 (most democratic), and its dimensions are competitiveness and openness of executive recruitment, constraints on the chief executive, and competitiveness and regulation of political participation.

Regarding control variables we opt for a parsimonious baseline model controlling only for income level (ln GDP per capita; mainly from the Maddison project, but we also test models using data from Gleditsch (2002)). Income level, which also correlates with other aspects such as class structure and urbanization that could affect education quality, is a particularly important control. Income is strongly correlated with democracy, and richer societies are presumably more likely to have the capacity to build and maintain high-quality education systems. Further, children of wealthier citizens - for various reasons such as better access to information technology (Jackson et al., 2006) and increased parental involvement in children's education (Desimone, 1999) - systematically perform better in school.

In many of our panel data models, we control for country-fixed effects since different country-specific factors, e.g. related to the historical characteristics of the education system 
or particular cultural traits, may affect education quality. Likewise time-fixed effects account for possible systematic time trends. For example, education quality might generally increase over time as we learn more about the measures improving it. While we consider the possibility of country-specific factors affecting education quality as highly plausible, and therefore prefer models including country-fixed effects, we also report cross-section and panel models without them for two reasons: First, given the moderately long time series and the slow-moving nature of democracy and education quality, fixed effects models could yield large standard errors. Fixed effects results could also be downward biased, due to the Nickell (1981) effect. A reported null-relationship in models including country-fixed effects could thus lead to a "Type II" error.

Also other factors can potentially affect education and correlate with democracy. We therefore report models including measures of income inequality (market income Gini, from Solt, 2009), natural resource income (ln oil and gas income, from Ross, 2012), and country size (ln population, from World Bank, 2011) in addition to income and the country and year dummies. Models controlling also for the latter three factors should thus mitigate omitted variable bias; if democracy is related to education outcomes in such models this would be a fairly strong result. Yet, these models risk "over-controlling" by taking out relevant channels that transmit indirect effects of democracy on education. Features such as income inequality (Acemoglu et al., 2015) or even population size (Przeworski et al., 2000) may be affected by democracy, and controlling for such covariates could introduce post-treatment bias. This is why we test both extensive and parsimonious specifications.

\section{Empirical analysis}

We start out by replicating the finding that democracy is positively related to measures of "education quantity", before moving on to test the relationship with education quality. In addition to our baseline analysis, we present models checking, for example, for nonlinearities in the relationship between democracy and education quality and whether the relationship depends on countries' level of income or quality of government. Finally, we present extensions on how democracy relates to different types of variability in education 
performance - both between different countries and among citizens in a given country - and how democracy relates to education performance in particular subjects, such as mathematics or reading.

\subsection{Democracy and measures of "education quantity"}

Table 1 reports our core specifications on education quantity, and alternative specifications are reported in Appendix Section A.4. In accordance with much of the literature we find positive, and mainly statistically significant, relationships between democracy and measures of education quantity. The dependent variable in Table 1 is average years of schooling for 25-year olds from the Barro and Lee dataset. Model A1 is a parsimonious OLS cross section regression, run on 120 countries. The dependent variable (averaged over 2005-2009) is regressed on the Polity Index and ln GDP p.c. (both averaged over 2000-2004). The coefficient for Polity is positive with a t-value of 2.37, suggesting that an increase from minimum to maximum Polity score is associated with 1.3 more average years of schooling. The result holds up well when adding other plausible controls. Model A2 adds the Gini measure of market income inequality, ln oil and gas income, and ln population, and shows very similar results as A1.

Model A3 is run on the entire 5-year period panel dataset, where the first time period is 1965-69 and the last is 2005-09, to incorporate within-country variation over time. A3 controls for income and country-fixed effects. Both the Polity coefficient and its t-value increase relative to the cross section models, suggesting that the democracy-schooling relationship is not driven by country-specific omitted variables related to, e.g., culture, geography or political history. The coefficient is weakened, but remains positive and with a p-value of 0.11 , when adding time-period dummies, oil and gas income, income inequality and population controls to the fixed effects model (A4).

Models trying to account for democracy being endogenous to years of schooling also show a positive, and often statistically significant, effect of democracy. For example, Models A5 and A6 are fixed effects 2SLS models that instrument for democracy by using WAVE from Knutsen (2011a). This variable records whether or not the last regime change (as identified by Polity's duration variable) was within or outside one of Huntington's "reverse 
waves of democratization" (Huntington, 1991) - time periods that were less and more conducive to democratization worldwide. WAVE has previously been used to estimate the effects of democracy on, e.g., property rights protection (Knutsen, 2011a) and civil conflict (Hegre and Nygård, 2015). The logic behind this instrument - which resembles the international "constitutional fashions" logic behind the instruments for electoral system and form of government created by Persson and Tabellini (2003) - is that WAVE taps exogenous, international-political sources of variation in countries' democracy levels. As Huntington (1991) details, the international climate for democratization has varied over time due to differing preferences by regional and global hegemonic powers (see also Boix, 2011) and to various learning- or other spill-over effects (see also Weyland, 2005) from neighboring countries undergoing democratization or de-democratization processes. These international trends should provide us with a source of variation in democracy that is presumably exogenous to the domestic education system. Concerning the exclusion restriction, we cannot think of any obvious theoretical reason for why the international-political environment under the last regime change should directly relate to the domestic education system, conditional on the other covariates.

WAVE turns out to be a strong instrument, as absolute t-values in the first stage are 9.9 and 7.2 for Models A5 and A6, respectively, and weak-instrument tests show F-statistics far beyond conventional critical values. Despite the theoretical rationale, one can, of course, never guarantee that the exclusion restriction is satisfied, although empirical tests sooth such concerns. $^{7}$ In any case, the parsimonious Model A5 reports a very large and statistically significant $(t=10.6)$ Polity coefficient, whereas the extensive Model A6 reports a smaller, positive estimate with a p-value of 0.11 .

In Appendix Section A.4 we report regressions testing alternative measures of education quantity (primary and secondary enrollment ratios) and democracy, alternative estimators, and alternative control sets. We consistently find a positive relationship between democracy and education quantity, and the relationship is most often statistically significant at conventional levels. ${ }^{8}$ 
Table 1: Democracy and average years of schooling

\begin{tabular}{|c|c|c|c|c|c|c|}
\hline & $\begin{array}{c}\text { A1 } \\
\text { OLS } \\
\text { Cross-sec. } \\
\text { b/t }\end{array}$ & $\begin{array}{c}\mathrm{A} 2 \\
\text { OLS } \\
\text { Cross-sec. } \\
\text { b/t }\end{array}$ & $\begin{array}{c}\text { A3 } \\
\text { OLS (FE) } \\
\text { 5-yr panel } \\
\text { b/t }\end{array}$ & $\begin{array}{c}\mathrm{A} 4 \\
\text { OLS }(\mathrm{FE}) \\
5-\mathrm{yr} \text { panel } \\
\mathrm{b} / \mathrm{t} \\
\end{array}$ & $\begin{array}{c}\text { A5 } \\
\text { FE 2SLS } \\
5-y r \text { panel } \\
\text { b/t }\end{array}$ & $\begin{array}{c}\text { A6 } \\
\text { FE 2SLS } \\
\text { 5-yr panel } \\
\text { b/t }\end{array}$ \\
\hline Polity Index & $\begin{array}{c}0.065^{*} \\
(2.37)\end{array}$ & $\begin{array}{c}0.076^{*} \\
(2.04)\end{array}$ & $\begin{array}{c}0.118^{* *} \\
(8.52)\end{array}$ & $\begin{array}{l}0.014 \\
(1.61)\end{array}$ & $\begin{array}{c}0.240^{* *} \\
(10.62)\end{array}$ & $\begin{array}{l}0.023 \\
(1.59)\end{array}$ \\
\hline Ln GDP p.c. & $\begin{array}{l}1.879^{* *} \\
(12.80)\end{array}$ & $\begin{array}{c}1.856^{* *} \\
(9.69)\end{array}$ & $\begin{array}{c}1.963^{* *} \\
(6.51)\end{array}$ & $\begin{array}{c}0.559^{* *} \\
(2.72)\end{array}$ & $\begin{array}{c}1.681^{* *} \\
(9.73)\end{array}$ & $\begin{array}{c}0.574^{* *} \\
(4.64)\end{array}$ \\
\hline Ln oil+gas income p.c. & & $\begin{array}{c}0.092 \\
(1.21)\end{array}$ & & $\begin{array}{c}-0.087^{*} \\
(-2.28)\end{array}$ & & $\begin{array}{c}-0.088^{* *} \\
(-3.80)\end{array}$ \\
\hline Gini (market income; reversed) & & $\begin{array}{l}0.044 \\
(1.58)\end{array}$ & & $\begin{array}{l}0.009 \\
(1.42)\end{array}$ & & $\begin{array}{l}0.009^{*} \\
(2.09)\end{array}$ \\
\hline Ln population & & $\begin{array}{c}-0.244+ \\
(-1.75)\end{array}$ & & $\begin{array}{c}0.699^{*} \\
(2.00)\end{array}$ & & $\begin{array}{c}0.717^{* *} \\
(3.75)\end{array}$ \\
\hline Period dummies & & & & $\mathrm{Y}$ & & $\mathrm{Y}$ \\
\hline Country dummies & & & $\mathrm{Y}$ & $\mathrm{Y}$ & $\mathrm{Y}$ & $\mathrm{Y}$ \\
\hline $\mathrm{N}$ & 120 & 104 & 1027 & 707 & 1019 & 698 \\
\hline
\end{tabular}

Notes: $+p<.10{ }^{*} p<.05 ;{ }^{*} p<.01$. T-values in parentheses. Dependent variable is average years of schooling for 25 year olds. All independent variables are lagged by 5 years, and standard errors are robust. WAVE from Knutsen (2011a) is used as instrument for Polity in the FE 2SLS models (see Appendix Section A.5 for first stage regressions). First time period is 1965-69, and final time period is 2005-2009. Constant, country dummies and period dummies are omitted from the table.

\subsection{Main analysis: Democracy and education quality}

Whereas democracy is strongly related to measures of how many citizens obtain education, and of how long they stay in school, we find no systematic relationship between democracy and education quality. For starters, the raw correlation between Polity and the aggregated student achievement test score measure from Angrist, Patrinos and Schlotter (2013) for the 2005-2009 period is .34, but the partial correlation is only .14 when accounting for differences in ln GDP per capita. ${ }^{9}$ In contrast, the partial correlation between the student test score measure and ln GDP per capita is close to .7, suggesting that the measure does not only pick up noise.

Figure 2 shows the deviation from the predicted mean test score - where the prediction is based on an OLS regression with ln GDP p.c. as the independent variable - along the yaxis, and Polity along the x-axis, for 95 countries measured in 2005-2009. There is basically no net relationship between democracy and education quality, when accounting for income level. Strongly overachieving countries can be found both among autocracies (e.g., Cuba) and democracies (Finland), and the same goes for underachievers (Kuwait and Mauritius, respectively). This is an initial indication that democracy does not explain variation in the knowledge and skills of students.

This null-relationship is corroborated in different regression models. Table 2 reports our 
Figure 2: Democracy and residualized mean student achievement test scores (net of ln GDP per capita).

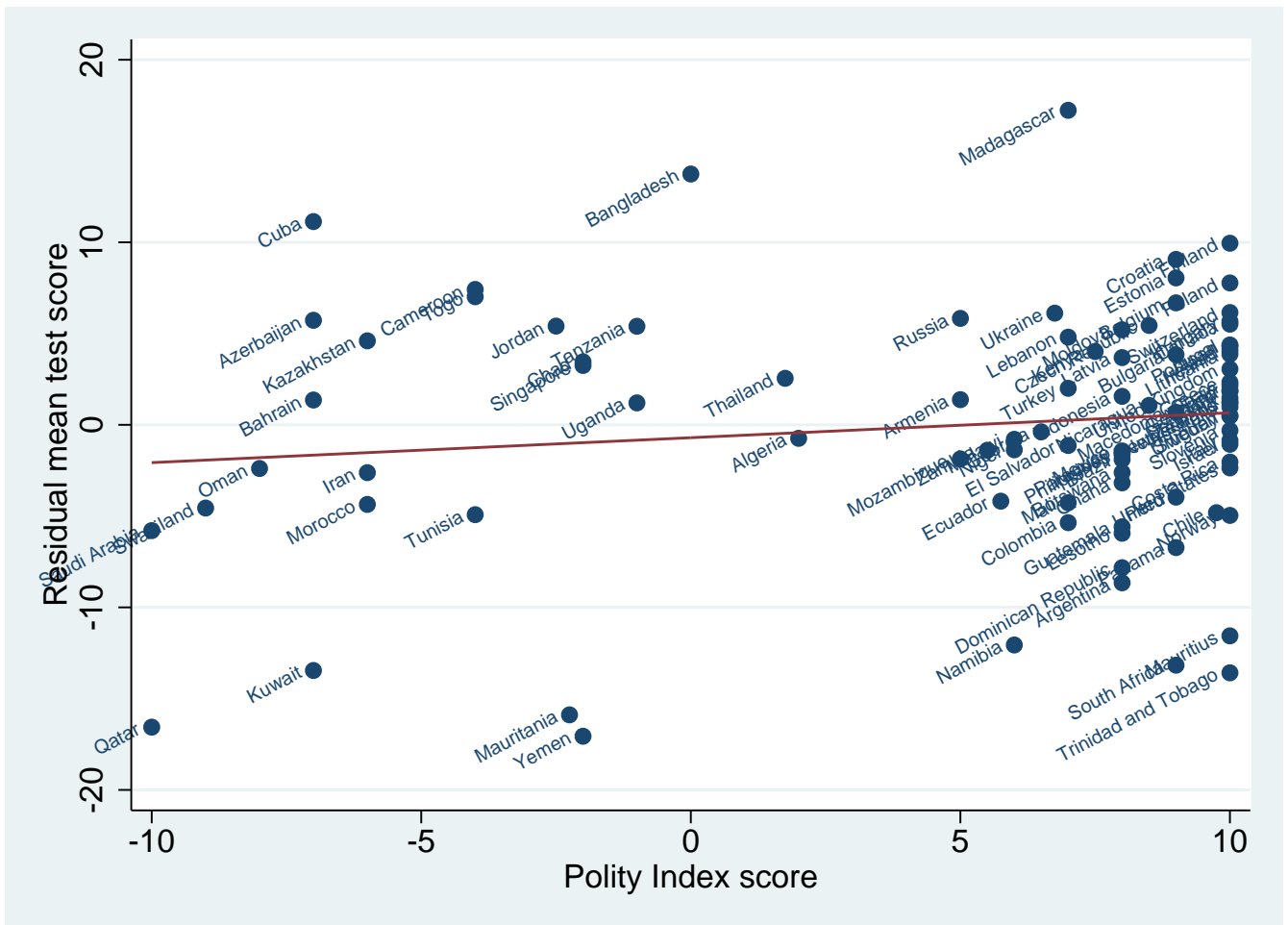

Note: The figure plots the residual (i.e. predicted - observed value from a regression with Ln GDP per capita as independent variable) of the mean student achievement test score measure from Angrist, Patrinos and Schlotter (2013) (y-axis), and the Polity Index (x-axis)

core models, which are similar to those in Table 1 but substitute average years of schooling with the test score measure. The cross section OLS regressions in Models B1 and B2 corroborate the lack of any systematic cross-country correlation between democracy and education quality, with t-values of 1.1 and 0.8 , respectively.

Given the lack of any relationship when drawing on cross-country comparisons, there is little reason to expect panel models controlling for country-fixed effects or accounting for the endogeneity of democracy to identify a relationship. If certain cultural factors (e.g., related to customs and norms highlighting individualism and strenuous work, Weber, 2002) or political-historical factors (e.g., related to colonial experiences and transmission of institutions enhancing political and economic development, Acemoglu et al., 2005) affect both educational outcomes and democracy, the extant literature suggests that these factors should affect them in the same direction. To take one example, Woodberry (2012) argues that the historic prevalence of Protestant missionaries, and the resulting conversionary Protestants, 
Table 2: Democracy and mean student achievements test score

\begin{tabular}{|c|c|c|c|c|c|c|}
\hline & $\begin{array}{c}\text { B1 } \\
\text { OLS } \\
\text { Cross-sec. } \\
\text { b/t }\end{array}$ & $\begin{array}{c}\text { B2 } \\
\text { OLS } \\
\text { Cross-sec. } \\
\text { b/t }\end{array}$ & $\begin{array}{c}\text { B3 } \\
\text { OLS (FE) } \\
\text { 5-yr panel } \\
\text { b/t }\end{array}$ & $\begin{array}{c}\text { B4 } \\
\text { OLS }(F E) \\
5-y r \text { panel } \\
\text { b/t }\end{array}$ & $\begin{array}{c}\text { B5 } \\
\text { FE 2SLS } \\
5-y r \text { panel } \\
\text { b/t }\end{array}$ & $\begin{array}{c}\text { B6 } \\
\text { FE 2SLS } \\
\text { 5-yr panel } \\
\text { b/t }\end{array}$ \\
\hline Polity Index & $\begin{array}{l}0.165 \\
(1.08)\end{array}$ & $\begin{array}{c}0.146 \\
(0.79)\end{array}$ & $\begin{array}{c}0.052 \\
(0.22)\end{array}$ & $\begin{array}{l}-0.029 \\
(-0.19)\end{array}$ & $\begin{array}{l}-0.186 \\
(-0.67)\end{array}$ & $\begin{array}{l}-0.017 \\
(-0.07)\end{array}$ \\
\hline Ln GDP p.c. & $\begin{array}{c}5.765^{* *} \\
(8.19)\end{array}$ & $\begin{array}{c}6.776^{* *} \\
(8.34)\end{array}$ & $\begin{array}{l}0.620 \\
(0.36)\end{array}$ & $\begin{array}{l}1.915 \\
(0.65)\end{array}$ & $\begin{array}{l}1.360 \\
(0.92)\end{array}$ & $\begin{array}{l}1.924 \\
(0.77)\end{array}$ \\
\hline Ln oil+gas p.c. & & $\begin{array}{l}-0.420 \\
(-1.40)\end{array}$ & & $\begin{array}{l}-0.322 \\
(-0.67)\end{array}$ & & $\begin{array}{l}-0.323 \\
(-0.64)\end{array}$ \\
\hline Gini (market income; reversed) & & $\begin{array}{c}0.429^{* *} \\
(5.88)\end{array}$ & & $\begin{array}{l}0.013 \\
(0.15)\end{array}$ & & $\begin{array}{l}0.013 \\
(0.16)\end{array}$ \\
\hline Ln population & & $\begin{array}{c}1.007+ \\
(1.76)\end{array}$ & & $\begin{array}{c}7.918+ \\
(1.86)\end{array}$ & & $\begin{array}{l}7.879^{*} \\
(2.07)\end{array}$ \\
\hline Period dummies & & & & $\mathrm{Y}$ & & $\mathrm{Y}$ \\
\hline Country dummies & & $\mathrm{Y}$ & $\mathrm{Y}$ & $\mathrm{Y}$ & $\mathrm{Y}$ & $\mathrm{Y}$ \\
\hline $\mathrm{N}$ & 91 & 84 & 341 & 321 & 317 & 297 \\
\hline
\end{tabular}

Notes: $+p<.10 ; * *^{*}<.05$; ** $p<.01$. T-values in parentheses. Dependent variable is mean student achievement test scores. All independent variables are lagged by 5 years, and standard errors are robust. WAVE from Knutsen (2011a) is used as instrument for Polity in the FE 2SLS models (see Appendix Section A.5 for first stage regressions). First time period is 1965-69, and final time period is 2005-2009. Constant, country dummies and period dummies are omitted from the table.

was a key factor behind reading skills and other education outcomes, historically, in Africa, Asia, Latin America and Oceania, and that such developments, in the end, helped induce democratization. If anything, cross-section results should thus be upwards biased, and accounting for country-fixed effects will alleviate common historical roots underlying both an effective education system and democracy.

Related, if democracy is endogenous to education quality, various contributions to modernization theory, for instance, indicate that high-quality education should enhance democracy (e.g., Lipset, 1959). Well-educated individuals are more politically active, also in autocracy-challenging protest movements (e.g., Glaeser, Ponzetto and Shleifer, 2007), and highly educated citizens are more capable in overcoming collective action problems and challenging autocratic regimes more effectively (e.g., Welzel, 2013). In contrast, we are unaware of plausible arguments suggesting that higher education quality should negatively affect democracy in a systematic manner.

Still, we run models accounting for country-fixed effects and the endogeneity of democracy to mitigate the possibility that any unforeseen "downward biases" are masking a positive effect of democracy in the cross country regressions - these models should, in any case, yield more consistent estimates. For the 2SLS models, which should also mitigate any attenuation bias stemming from random measurement errors in Polity, we again draw on the WAVE instrument capturing exogenous, international impulses on democratization. WAVE 
is a strong instrument, with absolute t-values around 8 in the first-stage regressions and F-test values surpassing any conventional threshold (see Appendix Section A.5). We see no clear theoretical reason to suspect that the exclusion restriction is violated; when conditioning on, e.g., income level and time period dummies, there is little reason to expect the international-political environment during the latest regime change to directly affect education quality except via affecting regime type domestically. ${ }^{10}$ As expected, neither the fixed effects OLS (B3-B4) nor fixed effects 2SLS models (B5-B6) identify any systematic relationship, with the t-values of the Polity coefficients ranging from -0.7 to 0.2 .

Our theoretical argument highlighted two potential reasons for why democracy may not enhance education quality, a hypothesis that finds clear support in the analysis above. The first relates to the lack of clear incentives for democratically elected politicians to pursue policies that may boost the quality of education, as politicians facing re-election in competitive races gain from rather focusing on more visible measures such as expanding the access to education. Second, even if democratic politicians may want to improve education quality, we highlighted the tenuous link between available and manipulable policy measures for national politicians and education quality. To further check the validity of our argument and gain insight into whether one or both of these mechanisms seem to explain the nullfinding, we run additional tests using various indicators of education spending.

Regarding the first part of the argument - on the lack of incentives for democratic politicians to pursue policies that could improve education quality - we investigate whether democracy is associated with both total education spending and spending per student. Results are reported and more thoroughly discussed in Appendix Section A.2. We highlight that the available data and simple cross-section designs that we must use should caution against drawing clear inferences. Still, these analyses provide some suggestive evidence supporting the electoral-incentive part of our argument. In brief, democracy is not correlated with higher levels of education spending per student, nor with total education spending. The latter result might be surprising since democracy enhances education enrollment. Yet, higher enrollment rates may not necessarily increase total spending levels by much if unit costs can be lowered by, e.g., increasing the number of students per teacher. (We do, indeed, find indications that democracies have more students per teacher in primary schools). In line 
with this, we also conduct mediation analysis suggesting that the effect of democracy on education quantity does not run through increased education spending.

The second part of the argument - on the difficulty of achieving education quality through political engineering - also receives support from cross-sectional regressions. Specifically, education spending is not clearly associated with higher levels of education quality, suggesting that politicians can not easily enhance education quality simply by channeling more funds to educational purposes.

\subsection{Robustness tests on democracy and education quality}

Different specifications and estimators: The null-relationship between democracy and education quality is robust in the sense that no OLS or 2SLS model with country fixed effects that we have tested give a positive Polity coefficient that is statistically significant at conventional levels. ${ }^{11}$ Still, the absence of any relationship in these models could be due to the relatively few observations and small number of time series units for each panel. The longest panel is only 9 time periods (each covering 5 years), and the average is 3.2 . With so few time series units, fixed effects estimates are both inefficient and downward biased (Nickell, 1981). But, the null-results remain for less restrictive pooled OLS and Random Effects (RE) models. The null-result is also retained in System GMM models, which are designed for short panels and for estimating effects of slow-moving variables (see Blundell and Bond, 1998). In contrast with the null findings for democracy, several of the control variables yield substantively large coefficients, and are often statistically significant. For instance, pooled OLS and RE models suggest that richer, more egalitarian and more populous countries have better education quality. We also find that natural resource rich countries produce worse education results.

Non-linear relationship: We probed different specifications to investigate whether our core models fail to pick up a potential non-linear relationship between education quality and democracy, or whether particular types of autocracies systematically fare better or worse than democratic regimes (see Appendix Section A.6). We included a squared polityterm to investigate the possibility that "semi-democratic" regimes fare worse in terms of education quality than both democracies and autocracies. However, only Fixed Effects OLS 
models suggest such a relationship, while other panel models and cross section regressions do not show signs of any non-linear relationship between democracy and education quality. We further tested specifications including dummy variables for both "full" and "partial" democracies (calculated from cut-offs on the Polity scale, drawing on Epstein et al., 2006), but find no systematic differences between the two regime categories, nor between these two regime categories and autocratic regimes. In sum, we do not find robust evidence of any systematic non-linearities in the relationship between democracy and education quality.

We also tested models including the autocratic regime dummies from Hadenius and Teorell (2007), and do find some evidence that autocratic monarchies perform systematically worse than democracies, and some indications that multi-party autocratic regimes perform better than democracies (but only when we omit the Polity variable from the regression). However, neither military regimes nor one-party autocracies differ systematically from democracies.

Context-dependent relationship: We further probed whether our null-results could mask that democracy matters for education quality in some contexts, but not in others. These results are also reported in Appendix Section A.6. We checked for an interaction between income and democracy, as democracy might matter for education quality only in rich-country contexts. Since primary school enrollment is close to universal in many rich countries, it could be that the political debate on education turns more towards improving quality (whereas democratic accountability mechanisms center on education expansion in poor countries). However, we find no evidence of any interaction between democracy and income on education quality. ${ }^{12}$

We discussed how institutions pertaining to the "quality of government" might enhance education quality, and we find some evidence of this in our cross-country regressions when using the composite QoG index, taken from Teorell et al. (2011). This measure is based on indicators of bureaucratic quality, rule of law, and corruption from the ICRG dataset (PRS Group, 2010). However, this result does not hold up in panel regressions. What is more relevant here, adding this measure does not affect the null-result for democracy. We also tested whether democracy matters more for education quality in countries with high quality of government, but do not find any clear evidence of a systematic interaction here either. 
Multiple imputation: We identify fairly clear (and sensible) results for several control variables, meaning that the relatively low number of observations is not an impenetrable barrier to identifying effects on education quality, if one exists. Still, the inefficiencies and potential selection biases resulting from the few data points might still account for the null-result on democracy. To alleviate this, we tested different models on the five imputed datasets constructed by using Amelia II (Honaker and King, 2010; Honaker et al., 2011). In brief, the imputation model takes into account the cross-section time-series data structure, using second-order polynomial country-specific time trends. Diagnostics and overimputation tests suggest that the imputation model performs quite well, although it predicts the most extreme education quality scores less well (see Appendix Section A.3). In order to provide as strong a test as possible on our main hypothesis, the imputation model was run so that it predicted observations for every country-year.

When using the imputed datasets, some parsimonious pooled OLS models report a statistically significant Polity coefficient (see Appendix Section A.7). However, this is likely due to omitted variable bias; when running Random Effects (RE) or Fixed Effects (FE) models, Polity turns statistically insignificant. Table 3 reports six RE and FE models that we tested on imputed data. These are parsimonious models with a 1-year lag on the independent variables. Coefficients are averaged over the 5 imputed datasets, and standard errors are imputation corrected. Models C1 (RE) and C2 (FE) includes income level, whereas C3 (RE) and $\mathrm{C} 4$ (FE) also include year dummies. The Polity t-values vary between -0.6 and 1.4 in these four models. ${ }^{13}$

Controlling for differences in education access: We highlighted in our theoretical discussion that the relationship between democracy and education quality might be attenuated by democracies expanding access of education to more citizens. This may generate capacity issues such as fewer teachers, textbooks, and square meters of class room per pupil. Still, our results on nation-wide averages of student achievement test scores may also be attenuated for a more subtle reason that should be considered more of a measurement issue: The background characteristics of the children that are typically given access to education under democracy but not autocracy (e.g., children of poor, rural voters; see Stasavage, 2005) might make them less likely to perform well in school and on student tests, ceteris paribus, 
Table 3: Democracy and mean student achievements test score: Imputed data

\begin{tabular}{|c|c|c|c|c|c|c|}
\hline & $\begin{array}{c}\mathrm{C} 1 \\
\mathrm{RE} \\
1-\mathrm{yr} \text { panel } \\
\mathrm{b} / \mathrm{t} \\
\end{array}$ & $\begin{array}{c}\mathrm{C} 2 \\
\text { OLS }(\mathrm{FE}) \\
1-\mathrm{yr} \text { panel } \\
\mathrm{b} / \mathrm{t} \\
\end{array}$ & $\begin{array}{c}\mathrm{C} 3 \\
\mathrm{RE} \\
\text { 1-yr panel } \\
\mathrm{b} / \mathrm{t} \\
\end{array}$ & $\begin{array}{c}\mathrm{C} 4 \\
\text { OLS (FE) } \\
1-y r \text { panel } \\
\text { b/t }\end{array}$ & $\begin{array}{c}\mathrm{C} 5 \\
\mathrm{RE} \\
1-\mathrm{yr} \text { panel } \\
\mathrm{b} / \mathrm{t} \\
\end{array}$ & $\begin{array}{c}\text { C6 } \\
\text { OLS (FE) } \\
\text { 1-yr panel } \\
\text { b/t }\end{array}$ \\
\hline Polity index & $\begin{array}{l}0.094 \\
(1.38)\end{array}$ & $\begin{array}{l}0.024 \\
(0.34)\end{array}$ & $\begin{array}{l}0.083 \\
(1.29)\end{array}$ & $\begin{array}{l}-0.037 \\
(-0.57)\end{array}$ & $\begin{array}{l}0.073 \\
(1.10)\end{array}$ & $\begin{array}{l}-0.041 \\
(-0.62)\end{array}$ \\
\hline Ln GDP per capita & $\begin{array}{c}5.074^{* *} \\
(5.12)\end{array}$ & $\begin{array}{c}3.414^{* *} \\
(3.51)\end{array}$ & $\begin{array}{c}4.701^{* *} \\
(3.92)\end{array}$ & $\begin{array}{c}1.478 \\
(1.33)\end{array}$ & $\begin{array}{c}2.824^{*} \\
(2.56)\end{array}$ & $\begin{array}{l}0.786 \\
(0.76)\end{array}$ \\
\hline Secondary school enrollment ratio & & & & & $\begin{array}{c}0.078 * * \\
(5.08)\end{array}$ & $\begin{array}{c}0.025+ \\
(1.99)\end{array}$ \\
\hline Year dummies & & & $\mathrm{Y}$ & $\mathrm{Y}$ & $\mathrm{Y}$ & $\mathrm{Y}$ \\
\hline Country dummies & & $\mathrm{Y}$ & & $\mathrm{Y}$ & & $\mathrm{Y}$ \\
\hline
\end{tabular}

Notes: $+p<.10 ; * p<.05 ; * * p<.01$. T-values in parentheses. Dependent variable is mean student achievement test scores. Country-year is unit of analysis, and all independent variables are lagged by 1 year. The coefficients are averaged over 5 imputed datasets, and standard errors are robust and imputation-corrected. The time series run from 1970-2011 (balanced panel). The log-transformed GDP p.c. variable is constructed as $\ln ($ GDP p.c. +18000$)$, due to the multiple imputation being conducted without bounds and the resulting occurrence of negative GDP p.c. values in the imputed datasets (see Appendix Section A.3 for details on the imputation model). Constant, country dummies and period dummies are omitted from the table.

than the children that typically have access both under autocracy and democracy (e.g., children of rich, urban elites). The lack of any positive relationship between democracy and aggregated education quality might therefore simply reflect expanded education access driving down democratic countries' average test scores.

This conjecture is admittedly difficult to test absent more nuanced measures or individuallevel data, although we note that our results in the next subsection, conducted on PISA 2012 results, suggest that democracy is not associated with higher variability in test scores within student populations, further alleviating concerns that this alternative mechanism is driving our results. Another implication is that the relationship between democracy and education quality should become stronger positive once controlling for measures of education access. This turns out not to be the case. We tested several models incorporating controls for primary and secondary enrollment ratios, and there is no evidence that the Polity coefficient subsequently increases (or is statistically significant, for that matter). Models C5 (RE) and C6 (FE) in Table 3 represent two such models, where both primary and secondary enrollment ratios are added to $\mathrm{C} 3$ and $\mathrm{C} 4$, respectively. The Polity coefficient actually decreases slightly in both models, suggesting that the null-relationship between democracy and the nation-wide average on student test scores does not come from democracies expanding education access to more kids. ${ }^{14}$ In sum, our analysis leaves little ground for optimism on the 
part of democracy in improving education quality.

\subsection{Extensions and some nuances}

Education quality in different subjects: The results presented so far rely on the aggregate indicator of student achievements tests that are based on (up to) six subcomponent scores, namely math, reading, and science test scores at the primary level and at the secondary level. Although we find no effect of democracy on this aggregate measure, democracies could still be systematically better at promoting certain types of education. For example, democracies may be better at promoting reading skills, but not science and math skills. Various East Asian and former Communist dictatorships in Eastern Europe have emphasized education in technical subjects, engineering, or natural sciences as opposed to social sciences and humanities (see, e.g., Hayhoe, 1995). One could hypothesize that a dictator looking to increase state revenues would find improving the natural sciences skills of citizens as one attractive option. Doing so increases the tax base by enhancing the productivity of the labor force, while such education may be less likely to serve the needs of oppositional forces wishing to build up protest movements or campaigns (see Stasavage, 2005).

To investigate this we re-ran selected models from Table 3, replacing our comprehensive education quality measure with the disaggregated measures available from Angrist, Patrinos and Schlotter (2013). We note, however, that we put less trust in these tests, as the disaggregated measures have lower coverage across countries and over time than the composite measure. This also means that we can only rely on the imputed datasets for conducting our tests. The results, reported and discussed more carefully in Appendix Section A.9, are thus only suggestive. In brief, Random Effects models - which are more efficient than corresponding Fixed Effects models, but potentially biased - provide no evidence that democracy is positively related to math skills. There are indications that democracy is positively related to reading skills, both at the primary and secondary levels, whereas democracy also correlates with science achievements at the primary (but not the secondary) level. But, when including country dummies, democracy is not systematically related to knowledge and skills in any of the three subjects, neither at the primary nor at the secondary level. 
Hence, while there are some indications that democracy is good for stimulating reading skills, more specifically, the evidence is far from robust and disappears when we account for country-fixed effects.

Variation in national-level outcomes: Our second extension relates to the variability in education quality in democracies and in autocracies, between countries, within countries over time, and within the student population in a given country. Although there is no difference in "average quality" between democracies and autocracies, autocracies could produce more outcome variation - as they have been shown to do for many other outcomes (such as economic growth; e.g., Rodrik, 2008). The higher concentration of political power within autocracies could make them more susceptible to the priorities and preferences of a small ruling elite, some of which may be highly concerned with education for various reasons, and others not.

To test this, we first run cross-section and panel models on education quality and next check for systematic differences in variation by employing Goldfeld-Quandt tests on the residuals, separating relatively democratic and relatively autocratic regimes using various operationalizations. We do, indeed, find that autocratic countries display more variability in education quality (see Appendix Section A.10). This result holds also when looking at variation within countries over time. Thus, even if predicted (average) education quality is not clearly related to regime characteristics, autocracies display more variation around their predicted level. In other words, democracies are less prone than autocracies to observe extremely bad, but also extremely good, education quality outcomes, also when accounting for income level and country-fixed effects.

Variation within student populations: Finally, one could expect that either autocracies or democracies display more variation in achievement tests also within their populations. That is, regime type could matter for the spread in skills and performance between "good" and "bad" students, even if the mean national levels are similar. However, the direction of such a relationship is hard to anticipate. Autocratic regimes might, for example, heavily favor children from their narrower supporting coalitions, suggesting larger spread within student populations in autocracies. Yet, democratization expectedly extends enrollment to student groups (such as sons and daughter of poor farmers) that may not have all the pre- 
requisites for performing well in school, and these students are often not in school (and are therefore not tested) in autocracies.

While the Angrist et al. dataset only includes country-aggregated scores, we can conduct more limited tests on regime type and within-population variation using data from the 2012 PISA test covering 56 countries. PISA mostly covers democracies, but 10 countries score lower than 6 on the Polity scale (and 8 score below 0, including as different countries as China, Jordan, Kazakhstan and Qatar). The results from regressions on the withinpopulation standard error in test performance - we separately tested this for mathematics, reading and science, at the primary and at the secondary level - show no signs of any systematic relationship, independent of whether we control for the mean test result in the population or not. Further analysis shows that regime type is not related to absolute gender differences in test scores either. Insofar as these cross-country tests on a modest number of countries are informative, there is no indication that democracy relates to the variability in performance within student populations.

\section{Conclusion}

In this paper, we have replicated the result that democracy relates positively to features of the education system such as the share of young citizens that attend school and the number of years they stay in school. This is congruent with extant findings from the literature, and with theoretical arguments highlighting how democratically elected politicians have incentives to address aspects of the education systems that are fairly visible to voters. However, we argued that democracy should not readily be expected to enhance the quality of the education that young citizens are exposed to, and thus the skills and knowledge that they obtain. Altering education quality is no easy matter for politicians, and democratic politicians may not even have strong incentives to try to alter them in the first place. Employing a panel dataset of international student test achievements, we find no clear evidence of any relationship between democracy and education quality, on average, although we do find indications that democracies display less cross-country variability in education quality outcomes than autocracies. Future data collection for more countries and preferably also for other subjects 
than mathematics, reading and science, will allow for even more appropriate testing of this relationship. Yet, our best guess, at current, is that democracy does not enhance the skills and knowledge of students.

Our findings have wider ramifications for venerable literatures on other subjects. It, for instance, bears on the suggested indirect effect of democracy on economic growth via increasing human capital. While several studies have identified a clear and positive indirect effect using measures of what we have termed "education quantity" (Tavares and Wacziarg, 2001; Baum and Lake, 2003; Doucouliagos and Ulubasoglu, 2008), analysis employing more appropriate measures of the actual knowledge and skills of the future work force would likely not identify any indirect effect, due to the non-existence of the first link in the causal chain. To illustrate this, we present the results of simple mediation analyses - with democracy as independent variable, the student performance measure as mediator, and economic growth as dependent variable - in Appendix Section A.8. The same might be the case for the proposed indirect effects of democracy via education on other outcomes of interest such as higher political participation, social trust and reduced political violence. This is because education is often theorized to stimulate political participation (Hillygus, 2005), as well as higher trust and fewer incidences of political violence (Thyne, 2006), mostly through enhancing knowledge and skills among citizens, and not simply through kids being in school. 


\section{References}

Acemoglu, Daron and James A. Robinson. 2006. Economic Origins of Dictatorship and Democracy. New York: Cambridge University Press.

Acemoglu, Daron, Simon Johnson, James A. Robinson and Pierre Yared. 2005. "From Education to Democracy." The American Economic Review 95(2):44-49.

Acemoglu, Daron, Suresh Naidu, Pascual Restrepo and James A. Robinson. 2015. Democracy, Redistribution and Inequality. Vol. 2 of Handbook of Income Distribution Elsevier pp. $1885-1966$.

Angrist, Noam, Harry Anthony Patrinos and Martin Schlotter. 2013. "An expansion of a global data set on educational quality: A focus on achievement in developing countries." Policy Research Working Paper WPS 6536.

Ansell, Ben. 2008. "Traders, teachers, and tyrants: democracy, globalization, and public investment in education." International Organization 62(2):289-322.

Ansell, Ben. 2010. From the Ballot to the Blackboard: The Redistributive Political Economy of Education. New York: Cambridge University Press.

Balzer, Harley. 1993. Science, Technology and Education in the former U.S.S.R. In The Former Soviet Union in Transition, ed. Richard Kaufman and John P. Hardt. Armonk: M.E. Sharpe pp. 889-908.

Barro, Robert J and Jong Wha Lee. 2013. "A new data set of educational attainment in the world, 1950-2010." Journal of Development Economics 104:184-198.

Baten, Joerg and Dácil Juif. 2014. "A story of large landowners and math skills: Inequality and human capital formation in long-run development, 1820-2000." Journal of Comparative Economics 42(2):375-401.

Bates, Robert H. 1981. States and Markets in Tropical Africa: The Political Basis of Agricultural Policy. Berkeley: University of California Press. 
Baum, Matthew A. and David A. Lake. 2003. "The Political Economy of Growth: Democracy and Human Capital." American Journal of Political Science 47(2):333-347.

Benos, Nikos and Stefania Zotou. 2014. "Education and economic growth: A meta-regression analysis." World Development 64:669-689.

Blundell, Richard and Stephen Bond. 1998. "Initial conditions and moment restrictions in dynamic panel data models." Journal of Econometrics 87(1):115-143.

Boesman, William. 1993. Science and Technology in the Former Soviet Union: Capabilities and Needs. In The Former Soviet Union in Transition, ed. Richard Kaufman and John P. Hardt. Armonk: M.E. Sharpe pp. 610-628.

Boix, Carles. 2003. Democracy and Redistribution. Cambridge: Cambridge University Press.

Boix, Carles. 2011. "Democracy, Development, and the International System." American Political Science Review 105(4):809-828.

Brown, David S. 1999. "Reading, writing and regime type: Democracy's impact on primary school enrollment." Political Research Quarterly 52(4):681-707.

Brown, David S. and Wendy A. Hunter. 2004. "Democracy and Human Capital Formation: Educational Expenditures in Latin America." Comparative Political Studies 37(7):842864.

Bueno de Mesquita, Bruce and Alastair Smith. 2009. "Political Survival and Endogenous Institutional Change." Comparative Political Studies 42(2):167-197.

Bueno de Mesquita, Bruce, Alistair Smith, Randolph M. Siverson and James D. Morrow. 2003. The Logic of Political Survival. Cambridge, MA: MIT Press.

Charron, Nicholas and Victor Lapuente. 2010. "Does democracy produce quality of government?" European Journal of Political Research 49(4):443-470.

Cheibub, José, Jennifer Gandhi and James Vreeland. 2010. "Democracy and dictatorship revisited." Public Choice 143(1-2):67-101. 
Chengze, Simon Fan, Jody Overland and Michael Spagat. 1999. "Human Capital, Growth, and Inequality in Russia." Journal of Comparative Economics 27(4):618-643.

Clarke, Christopher. 2006. Iron Kingdom: The Rise and Downfall of Prussia, 1600-194\%. London: Penguin Books.

Colclough, Christopher and Samer Al-Samarrai. 2000. "Achieving schooling for all: Budgetary expenditures on education in sub-Saharan Africa and South Asia." World Development 28(11):1927-1944.

Cooper, Harris, Jorgianne Civey Robinson and Erika A. Patall. 2006. "Does Homework Improve Academic Achievement? A Synthesis of Research, 1987-2003." Review of Educational Research 76(1):1-62.

Crayen, Dorothee and Joerg Baten. 2010. "Global trends in numeracy 1820-1949 and its implications for long-term growth." Explorations in Economic History 47(1):82-99.

Desimone, Laura. 1999. "Linking Parent Involvement With Student Achievement: Do Race and Income Matter?" The Journal of Educational Research 93(1):11-30.

Doucouliagos, Hristos and Mehmet Ali Ulubasoglu. 2008. "Democracy and Economic Growth: A Meta-Analysis." American Journal of Political Science 52(1):61-83.

Engerman, Stanley L., Elisa V. Mariscal and Kenneth L. Sokoloff. 2009. The Evolution of Schooling in the Americas, 1800-1925. In Human Capital and Institutions: The Long Run View, ed. David Eltis, Frank D. Lewis and Kenneth L. Sokoloff. Cambridge: Cambridge University Press pp. 93-142.

Engerman, Stanley L. and Kenneth L. Sokoloff. 2005. "The Evolution of Suffrage Institutions in the New World." Journal of Economic History 65(4):891-921.

Epstein, David L., Robert Bates, Jack Goldstone, Ida Kristensen and Sharyn O'Halloran. 2006. "Democratic Transitions." American Journal of Political Science 50(3):551-569.

Fuchs, Thomas and Ludger Woessmann. 2008. What accounts for international differences in student performance? A re-examination using PISA data. In The Economics of Ed- 
ucation and Training. Studies in Empirical Economics, ed. Christian Dustmann, Bernd Fitzenberger and Stephen Machin. Springer pp. 209-240.

Fullan, Michael. 2000. "The three stories of education reform." Phi Delta Kappan 81(8):581584.

Gallego, Francisco A. (2010). 2010. "Historical Origins of Schooling: The Role of Democracy and Political Decentralization." Review of Economics and Statistics 92(2):228-243.

Geddes, Barbara. 1999. "What Do We Know About Democratization After Twenty Years?" Annual Review of Political Science 2:115-144.

Glaeser, Edward L, Giacomo AM Ponzetto and Andrei Shleifer. 2007. "Why does democracy need education?" Journal of economic growth 12(2):77-99.

Gleditsch, Kristian S. 2002. "Expanded Trade and GDP data." Journal of Conflict Resolution 46(5):712-724.

Glewwe, Paul, Eugenie Maiga and Haochi Zheng. 2014. "The contribution of education to economic growth: A review of the evidence, with special attention and an application to Sub-Saharan Africa." World Development 59:379-393.

Hadenius, Axel and Jan Teorell. 2007. "Pathways from Authoritarianism." Journal of Democracy 18(1):143 -156.

Hanushek, Eric A. 2016. "School human capital and teacher salary policies." Journal of Professional Capital and Community 1(1):23-40.

Hanushek, Eric A and Dennis D Kimko. 2000. "Schooling, labor-force quality, and the growth of nations." American Economic Review 90(5):1184-1208.

Hanushek, Eric A and Ludger Woessmann. 2008a. "Education and economic growth." Chapters in Economics University of Munich, Department of Economics.

Hanushek, Eric A and Ludger Woessmann. 2008b. "The role of cognitive skills in economic development." Journal of Economic Literature 46(3):607-668. 
Hanushek, Eric A and Ludger Woessmann. 2011. "How much do educational outcomes matter in OECD countries?" Economic Policy 26(67):427-491.

Hanushek, Eric A and Ludger Woessmann. 2012a. "Do better schools lead to more growth? Cognitive skills, economic outcomes, and causation." Journal of Economic Growth 17(4):267-321.

Hanushek, Eric A and Ludger Woessmann. 2012b. "Schooling, educational achievement, and the Latin American growth puzzle." Journal of Development Economics 99(2):497-512.

Harding, Robin. 2015. "Attribution and Accountability: Voting for Roads in Ghana." World Politics 67(4):656-689.

Harding, Robin and David Stasavage. 2014. "What Democracy Does (and Doesn't Do) for Basic Services: School Fees, School Inputs, and African Elections." Journal of Politics $76(1): 229-245$.

Harris, Douglass N. and Tim R. Sass. 2011. "Teacher training, teacher quality and student achievement." Journal of Public Economics 95(7-8):798-812.

Hayhoe, Ruth. 1995. "An Asian multiversity? Comparative reflections on the transition to mass higher education in East Asia." Comparative Education Review 39(3):299-321.

Hecock, R Douglas. 2014. "Democratization, Education Reform, and the Mexican Teachers' Union." Latin American Research Review 49(1):62-82.

Hegre, Håvard and Håvard Mokleiv Nygård. 2015. "Governance and conflict relapse." Journal of Conflict Resolution 59(6):984-1016.

Hillygus, D Sunshine. 2005. "The missing link: Exploring the relationship between higher education and political engagement." Political Behavior 27(1):25-47.

Honaker, James and Gary King. 2010. "What to Do about Missing Values in Time-Series Cross-Section Data." American Journal of Political Science 54(3):561-581.

Honaker, James, Gary King, Matthew Blackwell et al. 2011. "Amelia II: A program for missing data." Journal of Statistical Software 45(7):1-47. 
Hoxby, Caroline M. 2000. "The Effects of Class Size on Student Achievement: New Evidence from Population Variation." Quarterly Journal of Economics 115(4):1239-1285.

Huber, Evelyn and John D. Stephens. 2012. Democracy and the Left: Social Policy and Inequality in Latin America. Chicago: University of Chicago Press.

Huntington, Samuel P. 1991. The Third Wave: Democratization in the Late Twentieth Century. Norman: University of Oklahoma Press.

Jackson, Linda A., Alexander von Eye, Frank A. Biocca, Gretchen Barbatsis, Yong Zhao and Hiram E. Fitzgerald. 2006. "Does home internet use influence the academic performance of low-income children?" Developmental Psychology 42(3):429-435.

Jamison, Eliot A, Dean T Jamison and Eric A Hanushek. 2007. "The effects of education quality on income growth and mortality decline." Economics of Education Review 26(6):771-788.

Jennings, Colin. 2015. "Collective choice and individual action: Education policy and social mobility in England." European Journal of Political Economy 40:288-297.

Knutsen, Carl Henrik. 2011a. "Democracy, Dictatorship and Protection of Property Rights." Journal of Development Studies 47(1):164-182.

Knutsen, Carl Henrik. 2011b. "Security Threats, Enemy-Contingent Policies and Economic Development in Dictatorships." International Interactions 37(4):414-440.

Kosack, Stephen. 2014. "The logic of pro-poor policymaking: Political entrepreneurship and mass education." British Journal of Political Science 44(2):409-444.

Kumah, Stephanie and Samuel Brazys. 2016. "Democracy or Accountability? Governance and Social Spending in Africa." Journal of Development Studies 52(2):286-299.

Lake, David A. and Matthew A. Baum. 2001. "The Invisible Hand of Democracy: Political Control and the Provision of Public Services." Comparative Political Studies 34(6):587621. 
Lindert, Peter H. 2005. Growing Public: Social Spending and Economic Growth since the Eighteenth Century. Volume 1. Cambridge: Cambridge University Press.

Lipset, Seymour Martin. 1959. "Some Social Requisites of Democracy: Economic Development and Political Legitimacy." American Political Science Review 53(1):69-105.

Loveless, Tom. 2011. Conflicting missions? Teachers unions and educational reform. Washington D.C.: Brookings Institution Press.

Lucas, Robert E. 1988. "On the Mechanisms of Economic Development." Journal of Monetary Economics 22(1):3-42.

Mankiw, Gregory N., David Romer and David N. Weil. 1992. "A Contribution to the Empirics of Economic Growth." Quarterly Journal of Economics 107(2):407-437.

Marshall, Monty G., Ted Robert Gurr and Keith Jaggers. 2013. "POLITY IV PROJECT: Political Regime Characteristics and Transitions, 1800-2012." Center for Systemic Peace.

Martin, Bradley K. 2004. Under the Loving Care of the Fatherly Leader: North Korea and the Kim Dynasty. New York: Thomas Dunne.

Meltzer, Allan and Scott Richards. 1981. "A rational theory of the size of government." Journal of Political Economy 89(5):914-927.

Michaelowa, Katharina. 2001. "Primary education quality in Francophone Sub-Saharan Africa: Determinants of learning achievement and efficiency considerations." World Development 29(10):1699-1716.

Moe, Terry M. 2011. Special interest: Teachers unions and America's public schools.

Murtin, Fabrice and Romain Wacziarg. 2014. "The democratic transition." Journal of Economic Growth 19(2):141-181.

Nickell, Stephen J. 1981. "Biases in Dynamic Models with Fixed Effects." Econometrica 49(6):1417-1426. 
North, Douglass C., John Joseph Wallis and Barry R. Weingast. 2009. Violence and Social Orders: A Conceptual Framework for Interpreting Recorded Human History. Cambridge: Cambridge University Press.

Olson, Mancur. 1982. The Rise and Decline of Nations. Economic Growth, Stagflation and Social Rigidities. New Haven: Yale University Press.

Persson, Torsten and Guido Tabellini. 2003. The Economic Effect of Constitutions. Cambridge: MIT Press.

PRS Group. 2010. "International Country Risk Guide Methodology." Political Risk Group. URL: http://www.prsgroup.com/PDFS/icrgmethodology.pdf

Przeworski, Adam, Michael E. Alvarez, José Antonio Cheibub and Fernando Limongi. 2000. Democracy and Development. Political Institutions and Well-Being in the World, 19501990. Cambridge: Cambridge University Press.

Rodrik, Dani. 2008. One Economics, Many Recipes: Globalization, Institutions, and Economic Growth. Princeton: Princeton University Press.

Ross, Michael. 2012. The Oil Curse: How Petroleum Wealth Shapes the Development of Nations. Princeton: Princeton University Press.

Rothstein, Bo. 2011. The quality of government: Corruption, social trust, and inequality in international perspective. Chicago: University of Chicago Press.

Rothstein, Bo and Jan Teorell. 2008. "What Is Quality of Government? A Theory of Impartial Government Institutions." Governance 21(2):165-190.

Saint-Paul, Gilles and Thierry Verdier. 1993. "Education, democracy and growth." Journal of Development Economics 42(2):399-407.

Sen, Amartya. 1999. Development as Freedom. New York: Anchor Books.

Solt, Frederick. 2009. "Standardizing the World Income Inequality Database." Social Science Quarterly 90(2):231-242. 
Sovey, Allison J and Donald P Green. 2011. "Instrumental variables estimation in political science: A readers'guide." American Journal of Political Science 55(1):188-200.

Stasavage, David. 2005. "Democracy and Educational Spending in Africa." American Journal of Political Science 49(2):343-358.

Stiglitz, Joseph E. 1997. Economics. Second Edition. New York: W.W. Norton.

Tavares, Jose and Romain Wacziarg. 2001. "How democracy affects growth." European economic review 45(8):1341-1378.

Teorell, Jan, Marcus Samanni, Søren Holmberg and Bo Rothstein. 2011. "The Quality of Government Dataset, version 6.".

URL: http://www.qog.pol.gu.se/data/qogstandarddataset/

Thyne, Clayton. 2006. "ABC's, 123's, and the Golden Rule: The Pacifying Effect of Education on Civil War, 1980-1999." International Studies Quarterly 50(4):733-754.

Weber, Max. 2002. The Protestant Ethic and "The Spirit of Capitalism". London: Penguin Books.

Welzel, Christian. 2013. Freedom rising. Cambridge University Press.

Weyland, Kurt. 2005. "Theories of Policy Diffusion Lessons from Latin American Pension Reform." World Politics 57(2):262-295.

Woodberry, Robert D. 2012. "The Missionary Roots of Liberal Democracy." American Political Science Review 106(2):244-274.

World Bank. 2011. "World Development Indicators." Washington, DC: World Bank.

URL: http://data.worldbank.org/data-catalog/world-development-indicators 


\section{Notes}

${ }^{1}$ Jamison, Jamison and Hanushek (2007) and Hanushek and Woessmann (2012a) find that education quality remains positively related to growth when using instrumental variables regression to account for endogeneity problems.

${ }^{2}$ For example, studies of Latin America have noted that the relatively low growth rates in the region cannot be explained by the high education levels, but when accounting for the poor quality of Latin American schools this "growth puzzle" is solved (Hanushek and Woessmann, 2012b).

${ }^{3}$ Nuancing this picture, Kosack (2014) argues that autocratic leaders may also face strong incentives to expand mass education when they rely on mobilizing the disorganized poor to stay in power. Moreover, Kumah and Brazys (2016) argues that accountability (which can also exist in autocracies), and not democracy, is the relevant feature for promoting investments such as education spending in Africa. But, there are also other arguments suggesting that democratic politics could increase education spending: Jennings (2015) argues that even voters without material incentives to further increase education spending could vote "expressively" for it (knowing they are unlikely to affect policy individually) due to ethical concerns.

${ }^{4}$ The public release of student achievements tests, such as PISA, have received attention in the public debate, especially in some OECD democracies. This could contribute to increasing transparency for attentive voters, for example by providing measuring sticks for cross-country comparisons. Yet, this is mainly a recent phenomena (occurring towards the end of our time-series).

${ }^{5}$ The impact of reforms on learning may also take time to materialize. While the time lag likely differs with the type of reform and context, Fullan proposes that "it takes about three years to achieve successful change in student performance in an elementary school. Depending on size, it takes about six years to do so in a secondary school" (Fullan, 2000, 1). Below, we experiment with different lag lengths when estimating effects on education quality, and our baselines employ 5 -year lags on the independent variables.

${ }^{6}$ The relationships between education (both quantity and quality) and democracy are stable for quite different democracy measures, including the minimalist measure from Cheibub, Gandhi and Vreeland (2010) and the maximalist from Freedom House.

${ }^{7}$ We cannot run standard overidentification tests with only one instrument. As an alternative (albeit an imperfect one, see Sovey and Green, 2011), we probed for a direct link between the instrument and schooling by including WAVE directly in fixed effects models otherwise similar to the second-stage regression. WAVE only obtains a t-value of 0.16 in 
the parsimonious model and -0.45 in the extensive model.

${ }^{8}$ One notable issue is possible sample selection bias, as many countries - especially autocratic - do not report education data. To deal with this we employed a multiple imputation model using Amelia II software from Honaker et al. (2011) to predict missing values at the country-year level. The exact specifications of the imputation model and tests evaluating its performance (which is quite good) are described when discussing education quality regressions including imputed data and in Appendix Section A.3. We constructed 5 imputed datasets and ran our regression models on these datasets using country-year as unit and employing imputation-corrected standard errors. The positive relationships between democracy and measures of education quantity turn out even clearer when including imputed data.

${ }^{9}$ The partial correlation is identical (.14) when lagging Polity with 5-years, and even lower when rather employing Freedom House's Political Rights Index (.04) or Civil Liberties Index (.11) as democracy measures.

${ }^{10}$ This is corroborated by further empirical tests, which do not show any link between WAVE and education quality once conditioning on democracy level and the control variables. These tests are discussed in Appendix Section A.5, which also reports and discusses alternative 2SLS specifications employing other instruments than WAVE.

${ }^{11}$ See Appendix Sections A.5-A.6. For example, we tested different error specifications than our baseline robust errors, e.g. clustering by country to account for panel-specific autocorrelation. In our baseline models the independent variables are lagged with one 5year period, but results are robust to, e.g., lagging the independent variables by 10 years. We note that some FE 2SLS specifications report a significant negative Polity coefficient, although we discuss in Appendix Section A.5 why we put less trust in these specifications.

${ }^{12}$ Likewise, we tested whether the relationship depends on whether societies are egalitarian or not, but fail to find any systematic interaction between Polity and the market income Gini coefficient.

${ }^{13}$ As displayed in Appendix Section A.7, the null-result is (mostly) retained when employing alternate democracy indices, lag structures, sets of controls, and when first-differencing the dependent variable to investigate how democracy affects changes in education quality.

${ }^{14}$ These results hold up when adding enrollment ratios to models not including imputed data. 